DOI https://doi.org/10.18551/rjoas.2018-06.01

\title{
HUNGARIAN FOREST MANAGEMENT TENDENCIES AT THE BEGINNING OF THE XXI CENTURY
}

\author{
Komarek Levente \\ Faculty of Agriculture, Economics and Rural Development Institute, \\ University of Szeged, Hungary \\ E-mail: komarek@mgk.u-szeged.hu
}

\begin{abstract}
Today, the forest is a key element of natural resources, the most complex natural (ecological) system in the continent. Because of its environmental impact, it is also a vital condition for healthy human life. In addition to its dominant role in regulating the quantity and quality of waters, the forest defines the nature of the landscape, preserves the richness of wildlife species and, being a renewable natural resource, continuously improves the state of the environment, while producing raw materials, energy sources and food. The present area and condition of forests have evolved over centuries of human activity. Due to their territorial fragmentation and the environmental damage forests are exposed to, we can only count on the indispensable survival, protective effect and products (yields) of forest communities if we treat them professionally and protect them from damaging effects, excessive use and stress, ensuring the diversity and appropriate harmony of their flora and fauna. The forest area of Hungary has grown dynamically over the last decades, however, in the European Union, we are one of the countries with less favourable indicators in this field. This study deals with the current issues of forest management in Hungary (forest area, forest land proportion, foresttree supply, afforestation, forest health, logging) focusing on the direction and extent of positive and negative changes in this field.
\end{abstract}

\section{KEY WORDS}

Forest area, forest land proportion, forest-tree supply, afforestation, forest health, logging, Hungary.

The forest is an ecosystem including the habitat as an integral part. The natural vegetation and fauna of the forest (together with the tree and the wildlife reserve) and the other natural and environmental values associated with the forest must be considered as a unit. As a habitat, it provides assurance for the survival of wildlife, it protects the soil, waters, cleans the air, gives rest to people, is a landscape element, while also providing material goods (Solymos, 2010).

One of the main principles and objectives of forest management in Hungary is the consistent and sustainable management of forests as a natural resource, which, at the same time, must meet the forest-focused environmental, social, recreational and consumption needs of society. Therefore, in addition to the owner, it is the society (the state) and not the users that are involved in financing forestry (Komarek, 2005b, 2007b, Solymos, 2010).

Due to its recoverability, within its natural distribution area, the forest, in contrast to many other ecosystems, can replenish and reproduce goods harvested there to satisfy human needs. Since a significant part of these goods - primarily wood - cannot be replaced with any other things, available only to a limited extent, or it is an environmentally friendly product or service that satisfies a basic need, we must attempt a reasonable forest management (Perczel, 2003).

Most of our forests are utilised by the public in the agricultural economy, with their mere existence they serve public objectives, with social, protective, holiday and recreational services. All this is true for the state and municipal forests. In our country, most public forests are in a recreation area, a landscape conservation area, a national park or they serve other recreational, environmental and nature conservation purposes, they are open to the public, therefore they are considered a public place and their maintenance is subject to budget 
support. All forests that have been created by public afforestation with total state subsistence and any new forest to be built for which the state provides support must be regarded as a private forest serving public purposes (Komarek, 2005c, 2007a, 2007b, Schiberna, 2001, Solymos , 2010).

As a result, forest management needs significant state support in market economies as well (state support means contributing to the extra costs of public service in the forest). The yields of forests provide low income (especially low return on equity), however, compared to other agricultural sectors, they are not even nearly supported. In the long run, the sociobudgetary support of uneconomic forests lacking resource is indispensable (Komarek, 2005a, 2005b, Solymos, 2006)

Domestic forests cannot be regarded as fully self-sustaining environmental systems as their present form has developed over centuries of human intervention and farming. Maintaining a large part of the forests in their present form and the usual level of services provided to society can only be carried out in the framework of good forest management (Komarek, 2005c, 2007a, 2007b, Schiberna, 2001, Solymos, 2010).

Over the past decades, the area extracted from agriculture has been growing since the regime change, with the increase of the integration degree of settlements, increasing dynamics of housing construction, greenfield industrial and other investment space requirements, road network and infrastructure development. The negative impact of this process on the quality of the environment is somewhat counterbalanced by the increase in the forest land proportion (Komarek, 2008, Yahid et al., 2006).

The forest, as a living community and habitat, depending on natural factors and human activity, is an indispensable part of the natural environment. It is also a renewable natural resource, so it must remain constant and it is important that it grow as possible. All this is done in accordance with the ownership and the public interest, its services and products are sold with market value. Accordingly, the forest area, its crop and income generation potential, ecological and intangible value cannot be reduced.

The forest should be used and utilised in a way and at a pace to maintain farming opportunities for future generations while the forest can conserve its biodiversity, nature, production, renewal and viability and meet the needs of the conservation and economic requirements, fulfil its role in reaching natural and environmental, health-social, tourism, educational and research purposes. Nevertheless, the rational use of the produced environmentally friendly, material return that is indispensable for society must not be abandoned either. Sustainability must be ensured in forest management. Sustainability means not only quantity but also quality (profitability, infrastructural services, protection effects). Ensuring profitability is a fundamental interest of professional and sustainable forestry. Financial support for farmers under unfavourable natural conditions is justifiable. The demand for forest products can only be met based on goods and services that can be provided by sustainable forest management. It is undesirable to reduce demand for wood consumption; the society should be encouraged to use wood, as the most environmentally friendly raw material, more widely (Komarek, 2008, Yahid et al., 2006).

The role of forests and wood in the next century can be greater than ever. Due to the long production cycle, we must prepare ourselves in time to ensure the needs of society at the right level. This means that forest management should have a place, better judgment and possibilities than before, in the agricultural sector as well as in the resolution of national economic tasks. In connection with this, it is helpful to accomplish the development of forestry and wood economy in harmony with other sectors, to ensure the best possible integration of the agricultural sector (Solymos, 2006, 2010).

The increase of the Hungarian forest area is far from what is accepted in the long-term programmes considered optimal, where sometimes the lack of financial resources has a significant role. Afforestation requires substantial capital; however, the return of the invested capital takes a relatively long time (Komarek, 2007b, 2008). 


\section{MATERIALS AND METHODS OF RESEARCH}

For the analysis, we used the county and national statistical data provided by the Hungarian Central Statistical Office $(\mathrm{KSH})$ as a data source. From the data, I developed indicators that enabled time and territorial comparative analysis of some Hungarian forest management indicators and the presentation of the main trends of the changes that took place. The analysis covers the past two decades.

In recent years, the transformation of Hungarian agriculture has led to significant temporal and territorial changes in forestry as well. These changes make it necessary to carry out studies that provide answers to the question if there were positive or negative changes in forestry, and which Hungarian regions have increased or decreased in this field during the past few years. To answer these assumptions, I applied mathematical-statistical methods for my analysis.

\section{RESULTS AND DISCUSSION}

Over the past 17 years, the size of the forest area was continuously increasing in Hungary. In 2017 the forest area was 1939.7 thousand hectares, which increased by $9.6 \%$, that is 170.1 thousand hectares, compared to that of 2000 (Figure 1).

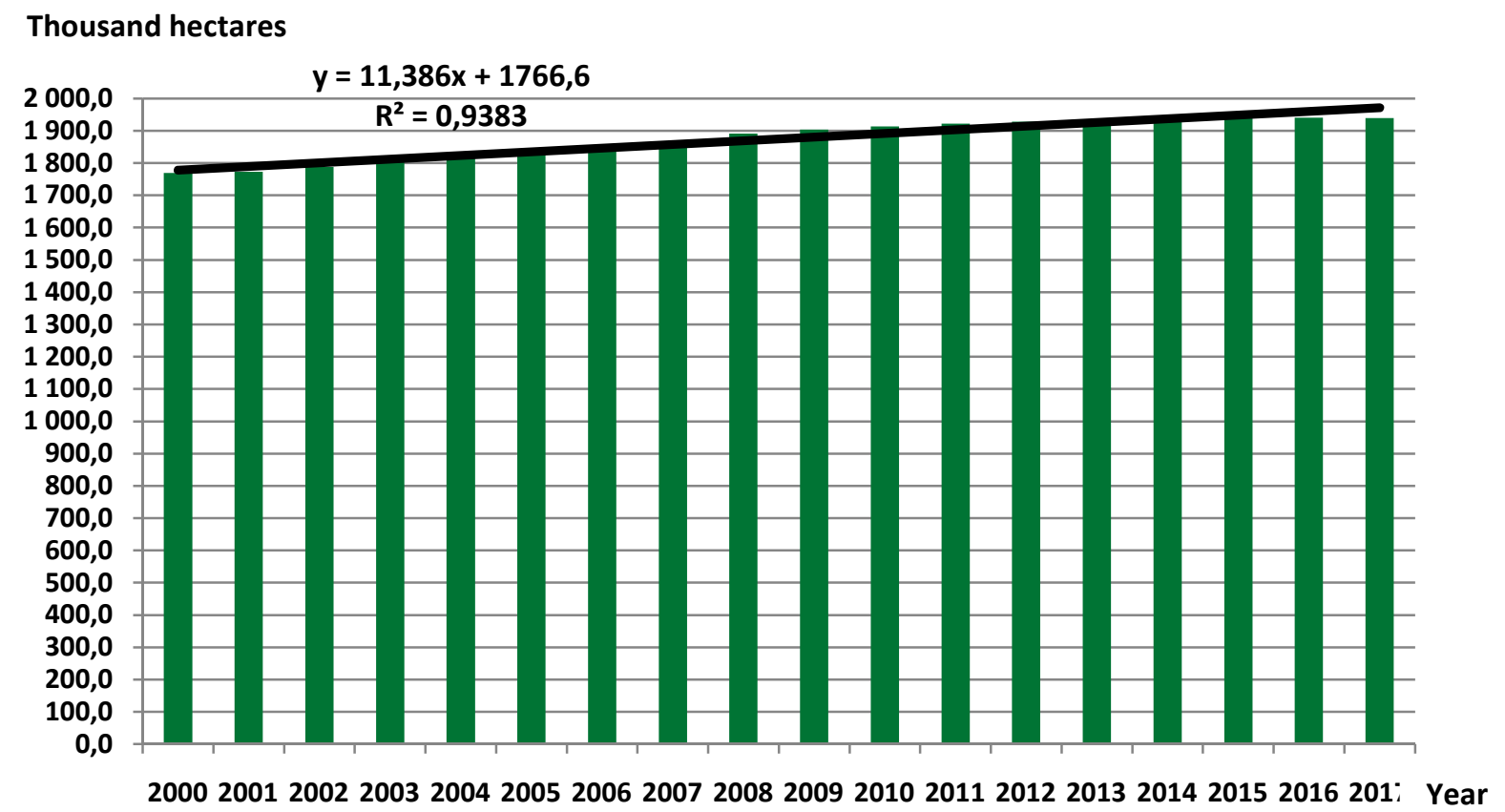

Figure 1 - Forest areas in Hungary, 2000-2017 (Source: Author's calculations, based on KSH data)

Forest areas are concentrated in Hungary. Extensive forests, mainly due to geological and climatic conditions, mostly developed in the hilly areas of Northern Hungary and Southern Transdanubia. In 2000, out of the counties it was Bács-Kiskun County that had almost the largest forest area (169.6 thousand hectares), which was $9.6 \%$ of the national value. Zala (168.8 thousand hectares - 9.5\%), Borsod-Abaúj-Zemplén (165.6 thousand hectares - 9.4\%), Somogy (162.1 thousand hectares - 9.2\%) and Pest (130.7 thousand hectares $-7.4 \%$ ) Counties also accounted for significant forest areas. The counties listed above gave $45.1 \%$ of the forest area of Hungary. Due to continuous afforestation, there was an increase in the forest area of the counties by 2017 compared to the base year (2000), which resulted in territorial changes at county level. That year, the largest forest area was in Borsod-Abaúj-Zemplén County (211.6 thousand hectares - 10.9\%). The forest areas of Somogy (179.0 thousand hectares - 9.2\%), Bács-Kiskun (175.9 thousand hectares - 9.1\%) and Pest (165.3 thousand hectares $-8.5 \%$ ) Counties were also outstanding. 
The proportion of forests - forest area from the total area - varies greatly depending on the territorial features. In 2000, the forest density in Hungary was $19.0 \%$ on the national average, which increased steadily over the 17 years and reached 20.9\% in 2017 (Figure 2).

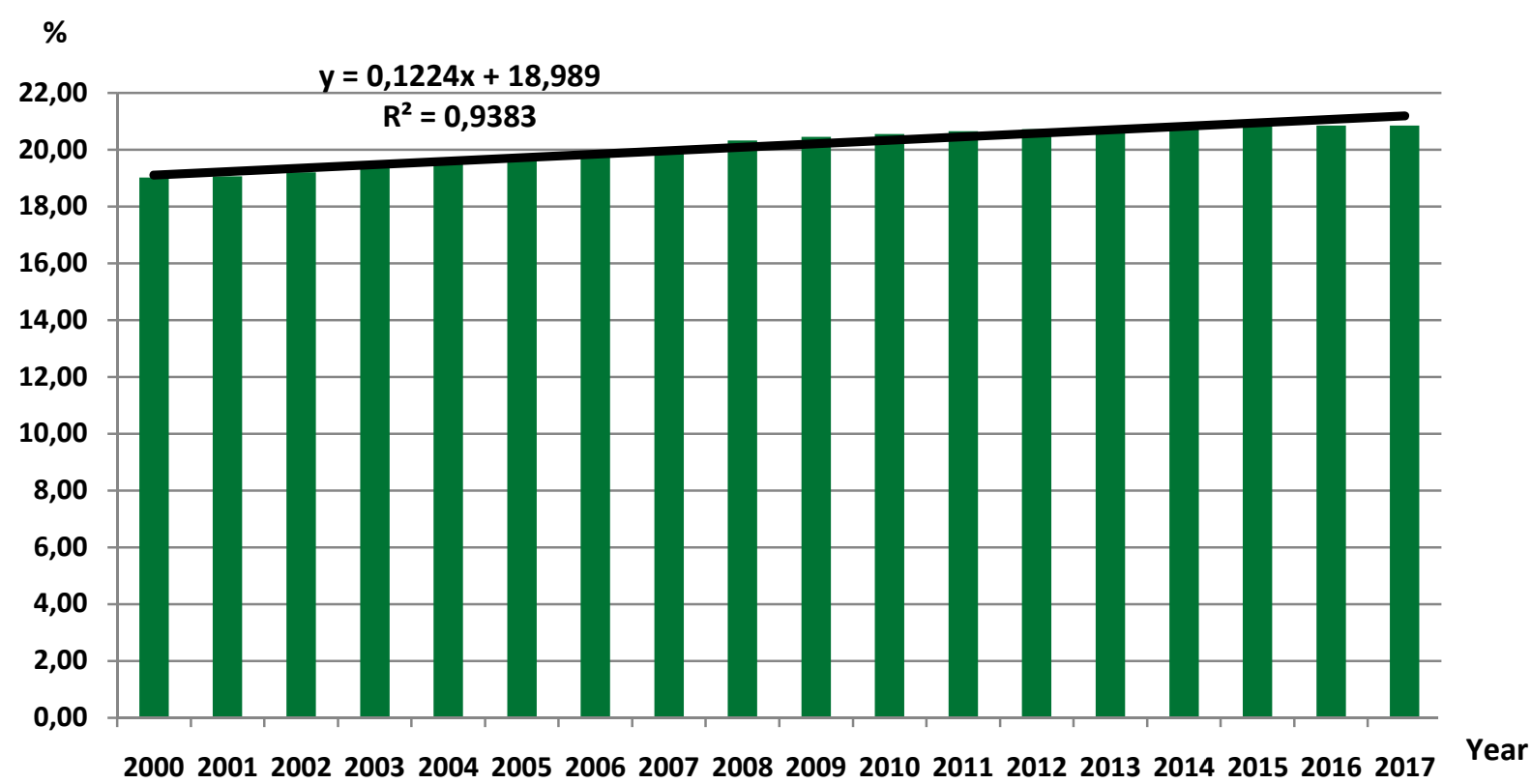

Figure 2 - Forest cover in Hungary, 2000-2017 (Source: Author's calculations, based on KSH data)

In 2000, the lowest number of forest areas in the region was in Central Hungary, however, the forest land proportion was higher than the national average (20.3\%). Western Transdanubia and Northern Hungary have the largest forests, and the forest land proportion is well above the national average $(19.0 \%)$, as most of their territory consists of hills. The forest land proportion in Western Transdanubia was 28.8\%, while in Northern Hungary it was $28.4 \%$ at the time of the research. The least afforested area was Northern Great Plain $(11.1 \%)$, where agricultural land is significant. Among the counties, the proportion of forests in Nógrád is exceptionally high (41.4\%), and it is also considerable in Zala (39.4\%), Somogy $(28.6 \%)$ and Heves $(28.2 \%)$. The forest land proportion was the smallest in Békés $(2.3 \%)$ (Figure 3).

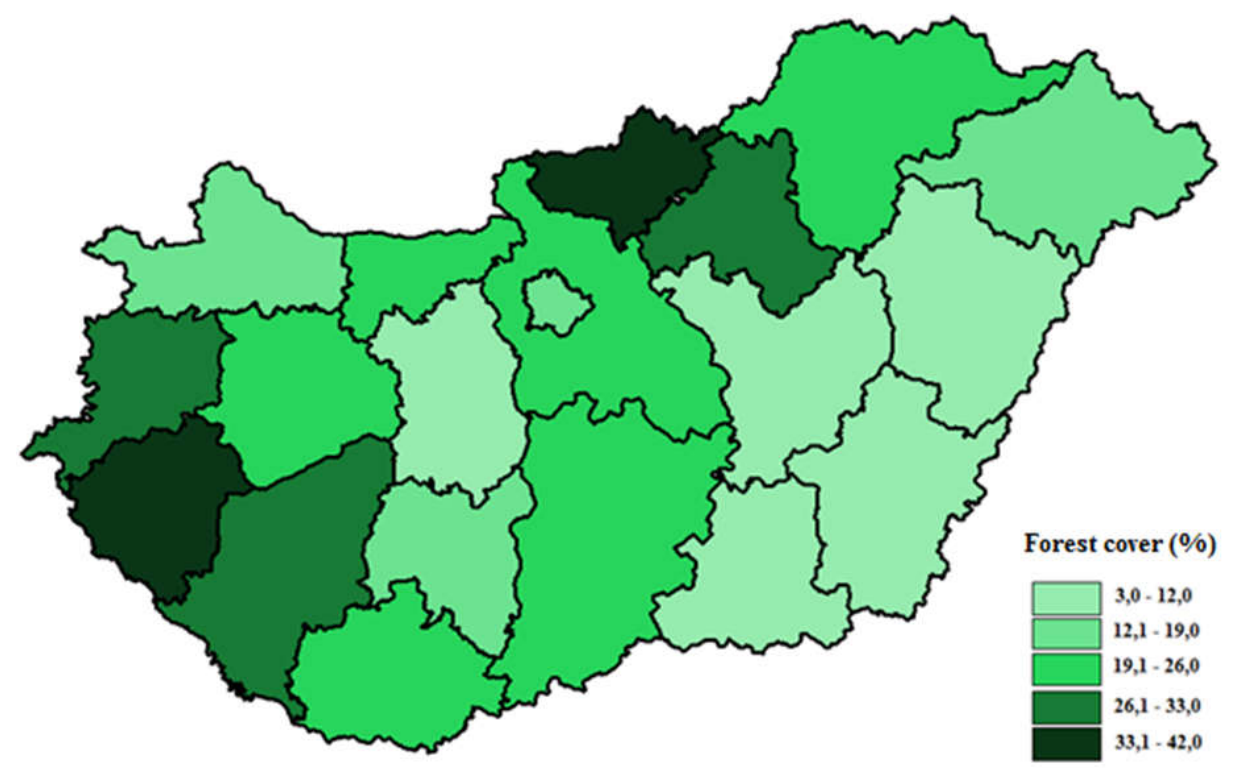

Figure 3 - Forest cover in Hungary by counties in 2000, \% (Source: Author's calculations, based on $\mathrm{KSH}$ data) 


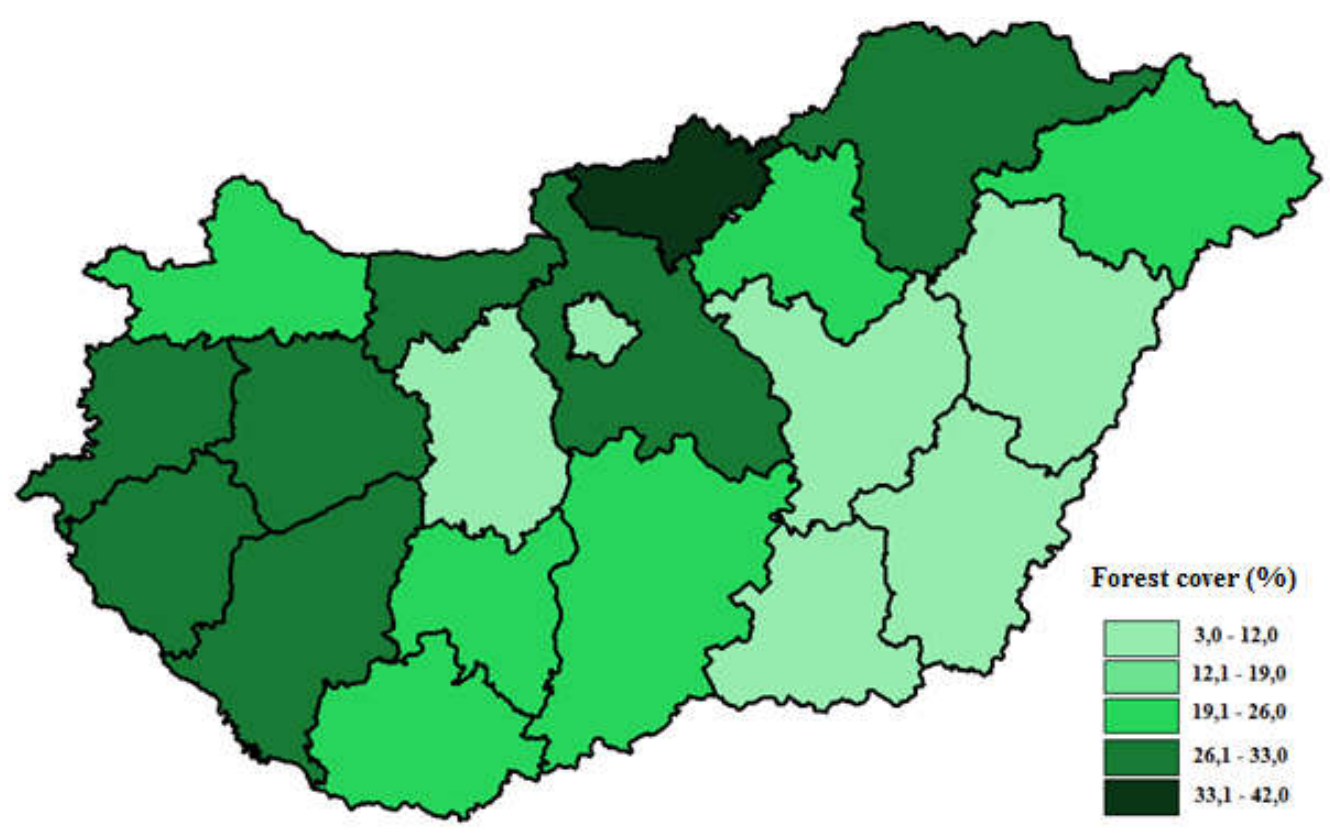

Figure 4 - Forest cover in Hungary by counties in 2017, \% (Source: Author's calculations, based on KSH data)

In 2017 there were no major changes in the order of forest land proportion in the regions. Due to the growth of forest areas, the forest land proportion of almost all regions has increased from 2000 to 2017. The exception is Western Transdanubia, where it has declined from the previous $28.8 \%$ to $26.3 \%$, caused mainly by a smaller disruption of the balance between afforestation and logging. As far as the other regions are concerned, Central Hungary still has the smallest forest area, yet the forest land proportion in this region (22.6\%) exceeds the national average $(20.9 \%)$. At the same time, Northern Hungary had the largest forest areas (399.8 thousand hectares) and forest land proportion $(30.5 \%)$ in the year of the examination. Despite the increase in the forest area of recent years, the Northern Great Plain is still the least afforested (12.5\%). Out of the counties it is in Nógrád (39.5\%), where the ratio of forests is still much higher than the national average. In addition to Nógrád County, Zala (32.7\%), Somogy (31.6\%), Veszprém (31.2\%) and Borsod-Abaúj-Zemplén (31.2\%) are also above the national average. The proportion of forests in Békés remains the smallest among the counties (4.7\%) (Figure 4).

Forest areas by purpose. Because of the new legislative changes that came into force in 2009, the proportion of forests for protection purposes - already more slowly though continued to grow at the expense of the forests for economic purposes (Table 1). Forests for protection purposes include forests for soil protection, water protection, settlement protection and nature conservation.

Table 1 - Hungarian forest areas by purpose, \%

\begin{tabular}{|l|c|c|}
\hline \multicolumn{1}{|c|}{ Name } & 2000 & 2016 \\
\hline Economic purpose & 74.5 & 61.6 \\
\hline Protection purpose & 23.2 & 37.3 \\
\hline Other purpose & 2.3 & 1.1 \\
\hline Altogether & 100.0 & 100.0 \\
\hline
\end{tabular}

Source: Author's calculations, based on KSH data.

The composition of forest areas and forest tree supply by tree species. The varied tree composition of Hungarian forests is determined primarily by the geographic location of the country, the climatic, hydrographic and soil conditions of the Carpathian Basin. Today, $63.3 \%$ of the forest area is native tree species, $36.7 \%$ is occupied by non-native or indigenous species (acacia, red oak, some pine species) or cloned varieties (noble poplar tree). In 2000, 
$85.9 \%$ of the 1769.6 thousand hectares of forest land was covered with deciduous trees, $14.1 \%$ were pine trees while $89.5 \%$ of the forest area, which increased up to 1939.7 thousand hectares, was covered by deciduous tree species and $10.5 \%$ by pine species in 2016 (Table 2).

In 2000, oak forests covering more than 367,000 hectares of hardwoods accounted for $21.1 \%$ of the wooded forest area. Oaks had more than 387,000 hectares $(20.7 \%)$ of timbercovered forest areas, an increase of $5.4 \%$ in 2016 , compared to 2000 . The growth during the examined period was mainly due to Békés and Szabolcs-Szatmár-Bereg Counties. The calculations show that the areas covered by the oaks increased, however their share from the national forest area decreased. Thus, the ratio of tree species shifted in the forest areas changed from 2000 to 2016, favouring acacia, poplar or other hardwood species. Nowadays approximately $20.0 \%$ of the oaks occur in Borsod-Abaúj-Zemplén County. Oaks are the most common species in the Northern Hemisphere, mainly the Cornish oak appears in great numbers. Somogy County also accounts for more than $10 \%$ of the oaks in the country, mainly thanks to the common oak. The distribution of oaks by age varies widely. On $12.0 \%$ of the area, there are trees over 10 years old, while on $9.5 \%$ of the area the tree population is over 100 years old. Considering the national territory, the former age group can be found in Somogy County, while the latter was in Borsod-Abaúj-Zemplén county with the highest proportion. The oak tree stock in 2000 was 82.8 thousand cubic meters, which increased to 87.1 thousand cubic meters in 2016 . By contrast, the share of the national living tree stock fell from the previous $25.4 \%$ to $23.3 \%$.

Table 2 - The composition of Hungarian forest areas and forest tree supply by tree species

\begin{tabular}{|c|c|c|c|c|}
\hline \multirow{2}{*}{ Tree species } & \multicolumn{2}{|c|}{2000} & \multicolumn{2}{|c|}{2016} \\
\hline & Area (\%) & Living tree (\%) & Area (\%) & Living tree (\%) \\
\hline Oak & 21.1 & 25.4 & 20.7 & 23.3 \\
\hline Turkey oak & 11.4 & 13.1 & 11.3 & 12.6 \\
\hline Beech & 6.2 & 12.0 & 5.9 & 10.7 \\
\hline Hornbeam & 5.9 & 5.5 & 5.2 & 4.7 \\
\hline Acacia & 21.5 & 12.1 & 24.4 & 13.6 \\
\hline Other hardwood & 4.5 & 4.4 & 6.2 & 5.9 \\
\hline Poplar & 9.8 & 6.5 & 10.5 & 8.4 \\
\hline Other softwood & 5.5 & 5.8 & 5.3 & 6.5 \\
\hline Scots pine & 8.3 & 10.0 & 6.2 & 9.4 \\
\hline Black pine & 4.1 & 3.3 & 3.2 & 3.1 \\
\hline Other pine species & 1.7 & 1.9 & 1.1 & 1.8 \\
\hline Altogether & 100.0 & 100.0 & 100.0 & 100.0 \\
\hline
\end{tabular}

Source: Author's calculations, based on KSH data.

Oak is also a significant tree species (Turkey oak), which is one of the main components of Hungary's most widespread forest associations, oak forests, in addition to Cornish oak. It occurs in medium mountains and hilly areas, mostly at 250-400 meters above sea level. In 2000 Turkey oak covered about 199,000 hectares of forest area, which grew to more than 211,000 hectares by 2016 . This represented a $6.0 \%$ increase from the base year to the examined year. The area of the oak grew in all counties except Komárom-Esztergom and Baranya Counties. Turkish oak covered $11.4 \%$ of the forest areas in 2000 , which fell back to $11.3 \%$ of all forest areas by 2016 . The largest area of Turkish oak is in Veszprém county, which exceeds 36 thousand hectares. $15.0 \%$ of the Turkish oak is $71-80$ years old. While the proportion of areas aged 10 years or younger is the highest in some of the Great Plain counties (Csongrád, Békés, Hajdú-Bihar), 18.0\% of Turkish oak woods in Budapest is over 100 years old. The living tree stock of the Turkish oak was 42.5 thousand cubic metres in 2000 , which increased to 46.9 thousand cubic metres by 2016 . Like that of the oak, its share of the national living tree stock decreased by 0.5 percentage points from 2000 to 2016 .

Beech trees form forests on hilly areas over 600-meter altitudes and on lower, but more humid Transdanubian regions. In Hungary, in 2000, their territory was more than 107,000 hectares, which rose to 111,000 hectares by 2016 (5.9\% of the forest area). The growth is due to Györ-Moson-Sopron and Vas Counties. 26.0\% of beech is in Borsod-Abaúj-Zemplén 
(Bükk-Hills), 16.0\% in Veszprém (Bakony), 14.0\% in Zala (Göcsej), and in Heves County (Mátra, Bükk) where their share was $10.0 \%$. Out of the forests $22.0 \%$ are over 100 years old and also $22.0 \%$ is between 81 and 100 years old. Considering the capital and the counties, the youngest $(8.7 \%)$ forests were in in Somogy while the rate of the oldest $(31.0 \%)$ was the highest in Budapest. Beech is a native tree species in Hungary; it can be used in many ways and its wood is easy to work with, and it is also of great importance for environment and nature conservation. In 2000 the living tree stock of beech was 39.1 thousand cubic meters, which increased to 39.7 thousand by 2016 . At the same time, the proportion of the living beech stock compared to the national figures decreased from the base year to in the examination year by $1.3 \%$.

In 2000 , hornbeam had nearly 103,000 hectares (5.9\%) share of the Hungarian forest area. By 2016 its area fell back to 97 thousand hectares (5.2\%). Its widespread associations are the oak-hornbeam forests, which occur mostly in hillsides and mountain ranges at the altitude of 400 to 600 meters. The largest area is in Borsod-Abaúj-Zemplén County (Bükk, Zempléni Hills). The hornbeam-Cornish oak forests have a significant area in Baranya County (Mecsek), Zala and South Somogy, in Zselicség. 14.0\% of the hornbeam belonged to the age group 71 to 80 years, while the proportion of the younger than 10 years was $2.8 \%$, and the age of more than 100 years was $6.8 \%$. In the other age groups, their proportion spread between $6.8 \%$ and $13.0 \%$. The group of 1 to 10 years of age had a share of $54.0 \%$ in Hajdú-Bihar, which has relatively small hornbeam area. At the same time, $22.0 \%$ of them in the Budapest area was older than 100 years in 2014. The living tree stock of hornbeam in 2000 was 17.9 thousand cubic metres, which decreased to 17.4 thousand by 2016 . This is also reflected in their share of the national stock, as it declined by 0.8 percentage points from 2000 to 2016.

The most common tree species in Hungarian forests is the acacia, providing $21.5 \%$ (373.3 thousand hectares) of all forest areas in 2000. By 2016 its area increased to 455.0 thousand hectares, which represents an increase of $21.9 \%$ compared to the year of the examination. The largest areas are in Bács-Kiskun County (60.2 thousand hectares), but Szabolcs-Szatmár-Bereg (56.4 thousand hectares) and Pest County as well (47.8 thousand hectares) have significant acacia areas. The area of this non-native tree species expanded in the examined period, mainly in the acacia-rich Szabolcs-Szatmár-Bereg and Bács-Kiskun Counties. $31.0 \%$ of the acacia forest area was aged between 11 and 20 years, $27.0 \%$ were in the age group of 21 to 30 , and the proportion of the 1 to 10 years was $21.0 \%$. The share of other age groups was $21.0 \%$. Out of the counties, Csongrád has the highest proportion $(33.0 \%)$ of young acacia forest (not older than 10 years). Its wood can be used in many ways: it is important firewood, because it can burn well even if it is moist, and its rich inflorescence makes it excellent for the bees to collect honey. On poor soils often, it is the only type of tree that can be considered for afforestation. The living acacia tree supply in 2000 was 39.2 thousand cubic meters, which increased to 50.7 thousand cubic meters in 2016. Growth is also reflected in the share of the national stock, as its share increased by $1.6 \%$ from 2000 to 2016 . The area of other hardwoods in 2000 was 78.3 thousand hectares, which increased to 115.9 thousand hectares by 2016 . This means about a $48 \%$ increase within 16 years. The living tree supply of other hardwood in 2000 was 14.3 thousand cubic meters, which rose to 22.1 thousand cubic meters in 2016. The increase is also reflected in the share of the national living tree supply, as its share increased by 1.5 percentage points from 2000 to 2016.

Poplar trees made up $56.6 \%$ (169.5 thousand hectares) of the softwood area (265.5 thousand hectares) in 2000, with a share of $6.9 \%$ of all forest areas. In 2016, the area increased from the previous 169.5 thousand hectares to 196.3 thousand hectares, an increase of $15.8 \%$ compared to the base year. Poplar(hybrid) plantations are used mainly as alleys and tree plantations on the river floodplains but also on other agricultural areas. Their occurrence is most common in Szabolcs-Szatmár-Bereg and Pest Counties (17-17\%). The living tree supply of poplar was 21.0 thousand cubic metres in 2000, which increased to 31.4 thousand by 2016 . This is also reflected in its share of the national living tree supply because the rate increased by $1.9 \%$ from the base year to the examination year. 
The indigenous Hungarian poplar, composed of several tree species, occur mainly in the plains, in the floodplain groves, in the deeper parts of the sandy areas of the Great Plain, and $44.0 \%$ of their forests are in Bács-Kiskun County (Homokhátság). The proportion of the Hungarian poplar area in 2000 was $2.9 \%$, which increased to $4.4 \%$ by 2016 . There are many poplar breeds that are currently in public use, which are also suitable for energy tree plantations due to their intense growth, good roots tendency and renewal ability. The living tree supply of Hungarian poplar grew by 1.5 percentage points from the base year to the year of the examination.

In 2000, the area of other softwood was almost 96,000 hectares (5.5\%), which increased to 98,000 hectares by 2016 . The proportion of the tree species was as follows: $22.0 \%$ linden, $21.0 \%$ willow and $7.3 \%$ other softwood. Alder or partly ash woods that are rich in moor-tree species and mostly covered in water in summer, mainly consist of alder. They inhabited especially the wider, flat valleys of hilly lands. More than half of the alder area is in Somogy County (Belső-Somogy, Zselic, Zákányi Hills). Alder is a soft tree suitable for aquatic constructions. The linden is typically a mixture-tree in the Carpathian Basin: it is frequent in the oak-and-hornbeam, beech, oak, floodplain woods and in rocky habitats. The largest linden forests were in Somogy, with a proportion of $27.0 \%$ out of the total area and Baranya County had a considerable linden area as well $(22.0 \%)$. The linden are probably the easiest, best carving wood available from any tree species. In the floodplain forests, the willow-poplar groves - also known as softwood - are the most common near the rivers. Nowadays, willow trees are planted on energy plantations due to their rapid growth. The willow woods occurred mostly in Győr-Moson-Sopron County (Szigetköz, Hanság) and Baranya County $(10.0 \%$ and $11.0 \%)$, while other species in this category were in Somogy $(41.0 \%)$. The living tree stock of other softwoods increased by 0.7 percentage point from 2000 to 2016.

In 2000, the pine forests owned 243.5 thousand hectares (14.1\%) of Hungarian forest area, out of which $59.0 \%$ was forest pine, $28.9 \%$ was Australian pine and $12.1 \%$ was other pine. By 2016, its area decreased to 195.0 thousand hectares, representing a $20.0 \%$ decline from the base year to the experiment year. Out of the pines, the area of other pines decreased to the greatest extent (33.6\%). In case of forest pine, the decline was $20.0 \%$ and for the black pine it was $14.0 \%$ from 2000 to 2016. Pine forests are located on 143,7 thousand hectares, mainly in Western Transdanubia, the largest area in Vas County (Alpokalja). One-third of the forest area is 31-40 years old, and one-fifths is 41-50 years old. The proportion of 10-year-old or younger forests is $1.5 \%$ (the highest in County Vas County), but there are also trees aged over 100 years, with a share of approximately $0.8 \%$.

Black (or Australian) pine had a 4.1\% share of domestic forests in 2000. By 2016 its proportion within domestic forests decreased to $3.2 \%$. In recent decades, it has been installed in dry sandy sites, which is why more than half of it is in Bács-Kiskun County. Its territory in all counties - except Jász-Nagykun-Szolnok - is less than in previous years.

Out of the other pine species the Norway spruce $(73.0 \%)$ is the most common, ahead of the red spruce $(16.0 \%)$ and other species $(11.0 \%)$. Spruce is a typical species of the continental climate requiring a minimum of 700 millimetres of rainfall per year, while in the rest period it is prefers cold sites, therefore it is present mostly in Vas $(25.0 \%)$, Zala $(22.0 \%)$ and Borsod-Abaúj-Zemplén (23.0\%). The total spruce-covered forest land decreased by almost $10.0 \%$, it fell back in each of the counties with a considerable size spruce area. The red spruce is the typical tree of mountains in the Northern Hemisphere. In Hungary, like spruce, they occur in higher, precipitous areas in Zala, Vas, Borsod-Abaúj-Zemplén Counties. The living tree supply of pine species in 2000 was 49.6 thousand cubic meters, which rose to 53.4 thousand cubic meters in 2016, however their proportion from the national supply declined by $1.2 \%$ from the base year to the reference year.

Afforestation. One of the main objectives of forestry policy is to increase the forest area through afforestation, up to a $26-27 \%$ forest proportion level. In the vegetation period of $2000 / 2001$ the total area of completed afforestation was 13.1 thousand hectares, which decreased to 2.5 thousand hectares for the 2012/2013 vegetation period. From the vegetation period of 2006/2007, except for the year of 2011/2012, the size of the completed 
afforestation area decreased continuously. Meanwhile, there is a high proportion of areas where, for some reason, successful afforestation is delayed. Among the complex causes why success takes that long, the role of weather extremes is significant. During the period under investigation, the highest proportion of area expansion occurred in Bács-Kiskun, due to the completed acacia, Hungarian poplar, and other softwood areas as well as the pine forests. Beech planting was accomplished in Borsod-Abaúj-Zemplén alone, while pine afforestation was declared as complete only in five counties (Pest, Győr-Moson-Sopron, Borsod-AbaújZemplén, Bács-Kiskun and Csongrád) (Table 3).

Table 3 - Afforestation (ha) by years

\begin{tabular}{|c|c|c|c|}
\hline Year & Afforestation & Replacement & Total \\
\hline $2000 / 2001$ & 13150 & 2366 & 15516 \\
\hline $2001 / 2002$ & 14830 & 2339 & 17169 \\
\hline $2002 / 2003$ & 12015 & 3013 & 15028 \\
\hline $2003 / 2004$ & 7574 & 4007 & 11581 \\
\hline $2004 / 2005$ & 7657 & 1782 & 9439 \\
\hline $2005 / 2006$ & 13989 & 1019 & 15008 \\
\hline $2006 / 2007$ & 18948 & 1341 & 20289 \\
\hline $2007 / 2008$ & 7332 & 2108 & 9441 \\
\hline $2008 / 2009$ & 5168 & 1135 & 6303 \\
\hline $2009 / 2010$ & 5096 & 864 & 3960 \\
\hline $2010 / 2011$ & 2803 & 658 & 5461 \\
\hline $2011 / 2012$ & 4537 & 472 & 3250 \\
\hline $2012 / 2013$ & 2530 & 720 & 1599 \\
\hline $2013 / 2014$ & 1287 & 312 & 452 \\
\hline $2014 / 2015$ & 318 & 134 & 300 \\
\hline
\end{tabular}

Source: Author's calculations, based on KSH data.

Overall, it can be observed that due to the afforestation of recent years, Hungarian forest areas continued to grow.

The health status of the forests. One of the prerequisites for fulfilling a wide range of expectations for the forest is to preserve the health of the forest, and to improve it as far as possible. The health conditions of Hungarian forests are dominated by weather conditions (drought, frost, ice, wind) and some biotic damages (mushrooms, insects), but the magnitude of damage caused by the game population is not negligible either. When classifying a state of health, harms can be grouped into three main categories - biotic, abiotic and unknown.

Table 4 - Health status of Hungarian forests (2000-2016)

\begin{tabular}{|c|c|c|c|c|c|}
\hline \multirow{2}{*}{ Year } & \multirow{2}{*}{ Asymptomatic (\%) } & Weakly & Moderately & Heavily & \multirow{2}{*}{ Dead (\%) } \\
\hline & & \multicolumn{3}{|c|}{ Damaged (\%) } & \\
\hline 2000 & 34.3 & 41.4 & 18.9 & 3.0 & 2.4 \\
\hline 2001 & 33.9 & 41.8 & 18.9 & 3.0 & 2.4 \\
\hline 2002 & 34.3 & 40.6 & 19.5 & 3.1 & 2.5 \\
\hline 2003 & 31.5 & 42.0 & 20.3 & 3.6 & 2.6 \\
\hline 2004 & 34.8 & 39.0 & 19.6 & 3.8 & 2.8 \\
\hline 2005 & 33.2 & 39.6 & 20.0 & 4.1 & 3.1 \\
\hline 2006 & 36.8 & 40.5 & 16.9 & 2.9 & 2.9 \\
\hline 2007 & 51.8 & 27.5 & 12.5 & 5.9 & 2.3 \\
\hline 2008 & 60.7 & 23.2 & 10.8 & 2.5 & 2.8 \\
\hline 2009 & 54.8 & 26.8 & 12.4 & 3.3 & 2.6 \\
\hline 2010 & 49.3 & 28.9 & 14.7 & 4.4 & 2.7 \\
\hline 2011 & 62.3 & 18.9 & 13.7 & 2.1 & 2.9 \\
\hline 2012 & 59.5 & 18.4 & 15.4 & 2.5 & 4.1 \\
\hline 2013 & 55.6 & 22.0 & 16.5 & 3.0 & 2.8 \\
\hline 2014 & 52.4 & 23.5 & 18.2 & 3.0 & 2.9 \\
\hline 2015 & 50.5 & 25.5 & 16.2 & 5.3 & 2.6 \\
\hline 2016 & 33.8 & 31.6 & 26.3 & 5.8 & 2.5 \\
\hline
\end{tabular}

Source: Author's calculations, based on KSH data 
Their proportion changed only slightly in the past year. Biotic damage still accounts for most damage, with a share of $54.8 \%$ of the total. Considering biotic damage, the rate of insect damage is the highest (27.7\%). This is followed by damage caused by various fungi $(11.5 \%)$. Damage caused by human activity $(6.9 \%)$, is mainly due to mechanical damage, approximation injuries. The rate of damage of other categories included here is $6.5 \%$. Wildlife damage represents $2.2 \%$. The second most commonly occurring injury category is an unknown source or degrading category. During the sampling, all the symptom groups that result from general degradation or linking damage of trees are included in this category. $33.2 \%$ of the damages belonged to this group. The abiotic damage, together with the fire damage listed separately, made up the $12.6 \%$ of the total damage.

Considering all the forest damage in Hungary in $2000,34.3 \%$ of the trees were asymptomatic, $41.4 \%$ were weakly, $18.9 \%$ were moderately, and $3.0 \%$ were heavily damaged. The proportion of dead trees reached $2.4 \%$. In 2016, 33.8\% of the trees were asymptomatic, $31.6 \%$ were weakly, $26.3 \%$ were moderately, while $5.8 \%$ were heavily damaged. The proportion of dead trees increased by 0.1 percentage point in the reference year compared to the base year (Table 4).

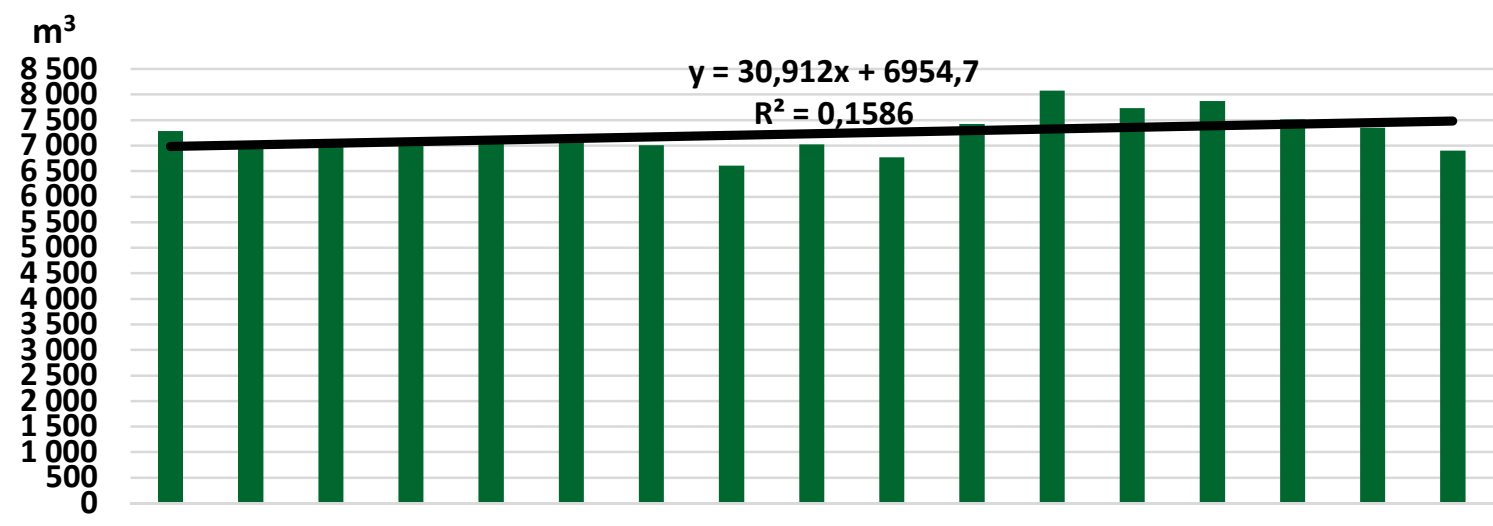

20002001200220032004200520062007200820092010201120122013201420152016 Year

Figure 5 - Logging in Hungary (2000-2016), \% (Source: Author's calculations, based on KSH data)

Table 5 - Logging by tree species in Hungary (\%)

\begin{tabular}{|l|c|c|}
\hline \multicolumn{1}{|c|}{ Name } & 2000 & 2016 \\
\hline Oak & 16.2 & 12.8 \\
\hline Turkey oak & 13.8 & 10.6 \\
\hline Beech & 9.4 & 9.8 \\
\hline Hornbeam & 4.6 & 3.5 \\
\hline Acacia & 20.5 & 19.3 \\
\hline Other hardwood & 2.5 & 3.6 \\
\hline Noble poplar & 14.7 & 14.5 \\
\hline Hungarian poplar & 2.8 & 3.4 \\
\hline Willow & 0.7 & 0.7 \\
\hline Other softwood & 3.2 & 3.7 \\
\hline Pine & 11.5 & 17.9 \\
\hline Total & 100.0 & 100.0 \\
\hline
\end{tabular}

Source: Author's calculations, based on KSH data.

Comparing the forest health results to the data of previous years we can conclude that in 2016 a significant deterioration was observed in the health of trees. The proportion of asymptomatic trees decreased by $16.7 \%$ compared to 2015 , while the proportion of endangered trees increased. The number of moderately damaged and heavily damaged trees also shows a slight increase. These changes may be considered more significant in contrast to the earlier low level of deterioration and it suggests that an unfavourable process has intensified in the forests, leading to a worsening of the health status of trees by 2016. All 
these negative changes occurred even though the weather of the past year was favourable in the vegetation period. The amount of precipitation was more than the average and monthly average temperatures were usually free from extremes. Deterioration was triggered by unfavourable weather conditions in previous years, the accumulating effects which appeared spectacularly in 2016.

Logging. Logging in the forests of Hungary is based on the principle of sustainability. In 2000 , the quantity of wood produced in 2000 , that is 7287 thousand $\mathrm{m}^{3}$, fell back to 6906 thousand $\mathrm{m}^{3}$ in 2016 (Figure 5). During the examined period, the development of timber production was uneven, but it had a growing tendency. Today, wood species that are most affected by logging are acacia, pine and noble poplar (Table 5). In 2016 there were 1336 thousand cubic meters of acacia produced, 1238 thousand cubic meters of pine, and 1000 thousand cubic meters of noble poplar (Populus $x$. euramericana) were produced.

\section{CONCLUSION}

Significant changes have taken place in the forest management of Hungary since the years following the regime change. Positive as well as negative directions can be observed in the changes.

In the year of the regime change (1990), Hungary had 1695.4 thousand hectares of forest area, which (2017) increased to 1939.7 thousand hectares by these days. It meant a $14.4 \%$ change from 1990 to 2017 . The steady growth of the forest-purpose areas has also resulted in an increase in the proportion of forests. Over the last 17 years, the proportion of Hungarian forest lands increased from the previous $19.0 \%$ to $20.9 \%$. The impact of this is also reflected at regional level, especially in those areas where forestry still has unexploited reserves (e.g. lowland counties). Afforestation accomplished during the past years played an important role in the growth of forest areas and in the proportion of forest lands.

During the examination period, the ownership structure was transformed. The forests, which were previously the property of co-operatives, became privately-owned again, and even part of the public forests was privatized. Despite the changes in the ownership structure, the role of the state remains dominant. In the case of forest areas, the proportion of forests with protection purpose increased compared with the forests for economic use.

There were changes in the composition of the tree species on forest areas and in the living tree supply. The forest area of some species increased (e.g. oak, beech, acacia), while others decreased (e.g. hornbeam, pine trees). A similar trend was observed in case of the living tree supply by tree species. Changes in many cases resulted in a proportional shift in the composition of forest areas and in the living tree supply. In many cases, the forest area and / or living tree supply of the given species increased, however its share from the national total decreased, compared to previous years.

Studies confirm that the health status of our forests continues to be good. However, due to climatic conditions, forest health has deteriorated compared to previous years. While the ratio of asymptomatic trees declined, the rate of threatened trees increased significantly.

The annual timber production has changed recently, the most affected species in logging were acacia, pine and noble poplar.

In my opinion, changes in forest management (forest area, forest land proportion, living tree supply, afforestation) have been encouraging in recent years to reduce our previous backlogs in this field and to catch up with the opportunities we are facing in the European Union. At the same time, it is important to note that, in addition to positive changes, negative changes should not be strengthened (for example, the deterioration of the health status of forests, exploitation) in the coming period, hindering the future dynamic development of Hungarian forestry.

\section{REFERENCES}

1. Komarek L. (2005a): Magyarország erdősültségének időbeni és területi alakulása. In: Puskás J. (szerk.): IV. Természet-, Müszaki- és Gazdasági Tudományok Alkalmazása 
Nemzetközi Konferencia, Berzsenyi Dániel Főiskola Művelődéstudományi és Kommunikáció Tanszék, Szombathely. pp. 1-6.

2. Komarek L. (2005b): Temporal changes in sylviculture in the marginal areas of the Great Hungarian Plains. pp. 549-533. In: Szónokyné Ancsin G. (szerk.): Határok és Eurorégiók: Nemzetközi Földrajzi Tudományos Konferencia. SZTE-TTIK Gazdaság- és Társadalomföldrajz Tanszék, Szeged. 581. p.

3. Komarek L. (2005c): A Dél-Alföldi Régió erdősültségének alakulása a rendszerváltozás utáni időszakban. ÖKO - Ökológia - Környezetgazdálkodás - Társadalom. pp. 113-119.

4. Komarek L. (2006): A rendszerváltozás utáni strukturális változások főbb jellemzői a DélAlföld mezőgazdaságában. In: Kertész Á., Dövényi Z., Kocsis K. (szerk.): III. Magyar Földrajzi Konferencia, Budapest, Magyarország. pp. 1-10.

5. Komarek L. (2007a): A földhasznosítás rendszerváltozás utáni módosulásai a DélAlföldön. pp. 325-332. In: Kovács Cs., Pál V. (szerk.): A társadalmi földrajz világai. [Becsei József professzor 70. születésnapjára]. SZTE-TTIK Gazdaság- és Társadalomföldrajz Tanszék, Szeged. 510. p.

6. Komarek L. (2007b): The structural changes in the agriculture of the South Great Plain since the regime change. pp. 329-339. In: Kovács Cs. (szerk.): From villages to cyberspace. In commemoration of the 65th birthday of Rezső Mészáros, Academician. SZTE-TTIK Gazdaság- és Társadalomföldrajz Tanszék, Szeged. 471. p.

7. Komarek L. (2007c): A Dél-Alföldi Régió súlyának, szerepének alakulása a hazai agrártermelésben. Comitatus - Önkormányzati Szemle. pp. 52-64.

8. Komarek L. (2007d): A hazai erdőgazdálkodás néhány indikátorának alakulása, különös tekintettel napjainkra. A Földrajz Tanítása - Módszertani Folyóirat. pp. 10-19.

9. Komarek L. (2008): A Dél-Alföld agrárszerkezetének sajátosságai. Csongrád Megyei Agrár Információs Szolgáltató és Oktatásszervező Kht, Szeged. 143 p.

10. Perczel Gy. (szerk.) (2003): Magyarország társadalmi-gazdasági földrajza. ELTE Eötvös Kiadó Budapest. 632. p.

11. Schiberna E. (2001): A magyar erdőgazdálkodás az európai uniós csatlakozás előtt. Európai Tükör, pp. 139-157.

12. Solymos R. (2006): Erdők és erdőgazdálkodás a szárazföld egyharmadán. Gazdálkodás. pp. 30-36.

13. Solymos R. (2010): Erdőgazdálkodás a klímaváltozás árnyékában. Erdészeti Lapok. pp. 410-415.

14. Vahid Y. - Vahidné Kóbori J. (2006): A világ erdőgazdálkodása és fakitermelése. Gazdaság és Statisztika (GÉS). pp. 3-17.

15. Electronic Source: www.ksh.hu 